\title{
RHEOMETRIC AND DYNAMIC MECHANICAL ANALYSIS OF COMPLEX NATURAL RUBBER BASED COMPOSITES
}

\author{
Aleksandra Ivanoska-Dacikj ${ }^{1 *}$, Gordana Bogoeva-Gaceva ${ }^{1,2}$, Sven Wießner ${ }^{3,4}$, Gert Heinrich ${ }^{3,4}$ \\ ${ }^{1}$ Research Center for Environment and Materials, Macedonian Academy of Sciences and Arts, \\ Krste Misirkov 2, 1000 Skopje, Republic of Macedonia \\ ${ }^{2}$ Faculty of Technology and Metallurgy, Ss. Cyril and Methodius University, \\ Rugjer Bošković 16, 1000 Skopje, Republic of Macedonia \\ ${ }^{3}$ Leibniz-Institut für Polymerforschung-Dresden, Hohe Straße 6, 01069 Dresden, Germany \\ ${ }^{4}$ Institut für Werkstoffwissenschaft, Technische Universität-Dresden, \\ 01062 Dresden, Germany \\ Corresponding author e-mail: aivanoska@manu.edu.mk
}

\begin{abstract}
This work describes the preparation and characterization of complex natural rubber (NR) based composites containing hybrid nano- and conventional fillers intended for base seismic application. Thorough rheometric and dynamic mechanical analyses in strain sweep mode at $2 \mathrm{~Hz}$ and $10 \mathrm{~Hz}$ (two frequencies laying in the range $0-15 \mathrm{~Hz}$ in which most of the earthquakes have the dominant frequencies) were performed on complex natural rubber (NR) based composites containing hybrid nanofiller (carbon nanotubes, expanded montmorillonite) and different amounts of conventional fillers like carbon black (CB) and silica. The rheometric studies showed that the influence of the combination of the different fillers on curing parameters is quite complex, but mainly the introduction of the fillers reduces the scorch and optimum cure time of the compounds. The dynamic mechanical analysis showed a pronounced non-linear strain dependence of the storage modulus and a remarkable increase of the loss factor tan $\delta$ for all composites, especially for those containing high CB content, compared to the NR-gum. To describe this strain-dependency of the storage modulus the cluster-cluster aggregation (CCA) model was used. The values of the fitting parameters $\Delta E_{0}^{\prime}, \gamma_{c}$, and $E_{\infty}{ }_{\infty}$ calculated by this model show that they are affected by the type of the fillers present in the NR matrix and also by the applied frequency.
\end{abstract}

Keywords: natural rubber; hybrid composites; rheometric study; filler networking; Payne effect

\section{INTRODUCTION}

Natural rubber (NR) is used extensively in many different industrial and structural applications due to its outstanding mechanical properties: high resilience, high tensile and tear properties and good crack growth resistance. The mechanical properties of rubber as a soft material mostly depend on reinforcement by fillers which are an inevitable ingredient in rubber compounds. Colloidal fillers, like carbon black (CB) or silica, play an important role in this improvement of the mechanical properties of high performance rubber materials. However, due to their high structure and tendency to agglomerate, strong shear fields or filler modification are needed to ensure fine dispersion. Furthermore high quantities are needed to provide a sufficiently high level of reinforcement but on detriment of elasticity [1].

Besides these conventional fillers which are used to modify rubber properties for more than a century, the application of a new class of fillers nanofillers, has attracted a huge scientific interest in this last decade. The implementation of novel nanofiller systems like layered double hydroxides [2], organomodified nanoclays [1, 3-10], halloysites and carbon nanotubes (CNT) [11-16] in elastomeric matrices is a subject of an intense research. The most investigated, thanks to their unique properties 
and demonstrated abilities to enhance the mechanical properties of elastomers, are layered silicates [1, 3-10] and carbon nanotubes (CNT) [11-16]. Montmorillonite (Mt) is commonly used owing to its large availability, low cost, high surface area and high cation exchange capacity. CNT on their behalf, are of particular interest due to their exceptional combinations of physical properties such as high aspect ratio, large flexibility, low density and superior electrical and thermal properties [17].

But not all desired properties of the filled rubber could be achieved by addition of low quantities of nano-particles. For instance, the energy dissipating capacity, a property that is significant in the design of structures and mechanical devices connected to problems involving mechanical resonance and fatigue, shaft whirl, heating and cyclic stress, is mainly governed by the filler-filler interactions and demands higher quantities of filler present in the rubber matrix.

Therefore, recently, an increasing interest is becoming evident for hybrid systems based on both nanofillers and conventional fillers [18-21]. These works show significant enhancement of material dynamic-mechanical properties thanks to the use of the hybrid filler system. It was reported by Galimberti et al. $[18,21]$ that the initial modulus values obtained with the hybrid $\mathrm{CB}$-organo-montmorillonite (OMt) and CB-nanographite filler systems are much higher than those calculated through the simple addition of the two initial moduli of the composites containing only conventional fillers or only nanofillers.

In this study we performed thorough rheometric and dynamic mechanical analyses on complex NR based composites containing both nanoand conventional fillers. As a hybrid nano-filler a combination of $2 \mathrm{phr}$ of multi-wall carbon nanotubes (MWCNT) and $16 \mathrm{phr}$ of expanded organomontmorillonite (EOMt) was used. The optimization of this ratio was done in our previous study [22]. The overall content of the conventional fillers in all composites was kept constant at $40 \mathrm{phr}$ in which the content of the individual fillers $\mathrm{CB}$ and silica were varied form $0 \mathrm{phr}$ to $40 \mathrm{phr}$. Our interest was to investigate how the different combinations of fillers influence the processability and crosslinking of the rubber compounds. The main goal was to explore the rubber-filler and filler-filler interactions in order to understand the mechanism of energy dissipation in these complex NR-based systems. Wang [23] suggested that breakdown and reformation of the filler network, accompanied by the release of the trapped rubber from the filler network, causes an energy dissipation process during dynamic deformation. This mechanism suggests that the Payne effect or strain dependence of dynam- ic modulus of rubber can serve as a measure of filler networking which originates from filler-filler interaction as well as polymer-filler interaction [23].

DMA strain sweep measurements, carried out by applying cyclic deformations in the tensile mode at two different frequencies, $2 \mathrm{~Hz}$ and $10 \mathrm{~Hz}$, respectively, were used to determine the loss factor, $\tan \delta$ and $G^{\prime}$ (storage) modulus. This study is part of a wider project which purpose is obtaining complex rubber compound suitable for base seismic isolation and these frequencies, seemingly quite close to each other, lay in the range in which most of the earthquakes are dominant and that is $0-15 \mathrm{~Hz}$ [24]. Finally, the CCA-model was implemented to understand more deeply the Payne effect, the strain dependency of the storage modulus, which is considered to be one of the mechanisms of energy dissipation.

\section{EXPERIMENTAL}

\section{Materials}

The rubber compounds were based on natural rubber (NR) using a Standard Malaysian Rubber grade (SMR 10). The Organo-Montmorillonite (OMt) used was Nanofil 15 supplied from SüdChemie AG Moosburg, Germany. Distearyl dimethylammonium chloride (QUAT) was used as an organic modifier. The specific gravity of this $\mathrm{OMt}$ was $1.8 \mathrm{~g} / \mathrm{cm}^{-3}$ with an average particle size of 25 $\mu \mathrm{m}$. Carbon nanotubes, NC7000, a multiwall carbon nanotubes (MWCNT) produced by catalytic carbon vapor deposition (CCVD) process, were supplied by NANOCYL S. A. (Belgium). They were $90 \%$ pure containing $10 \%$ metal oxides and had an average diameter of $9.5 \mathrm{~nm}$ and an average length of $1.5 \mu \mathrm{m}$. The stearic acid was purchased from ACROS Organics, Geel, Belgium with 97\% purity. The vulcanizing accelerators N-tert-Butyl-2benzothiazolesulphenamide (TBBS) and N-cyclohexyl-2-benzothiazolesulphenamide (CBS) were kindly provided from Rhein Chemie Rheinau $\mathrm{GmbH}$, Mannheim, Germany. The carbon black was Corax N 330 (ORION Engineered Carbons $\mathrm{GmbH}$, Köln, Germany), silica filler used was Ultrasil VN3 (Evonik Industries AG, Germany). Sulfur (S), N-(1, 3-Dimethylbutyl)-N'-phenyl-p-phenylenediamine (6PPD) and zinc oxide $(\mathrm{ZnO})$ used in this study were of industrial grade.

\section{Preparation of the hybrid rubber composites}

The procedure of preparation of the expanded organo-montmorillonite (EOMt) is described in detail in ref. [22]. For the compounds containing 
nanofillers, the MWCNT were firstly dispersed in ethanol in a ratio $1: 20$ by weight. This pre-dispersion is required regarding the safe manipulation of the MWCNT, but it also enhances their dispersion in the rubber [16]. Then the batch composed of 100 phr NR and 10 phr MWCNT was mixed in an internal mixer (Haake Rheomix) at a fixed rotor speed of $60 \mathrm{rpm}$, at $90{ }^{\circ} \mathrm{C}$ for $20 \mathrm{~min}$. Afterwards, this masterbatch was diluted with NR to a target of $2 \mathrm{phr}$ MWCNT and was mixed together with $16 \mathrm{phr}$ of EOMt, N330 and Ultrasil VN3 (for both fillers content was varied from 0 to $40 \mathrm{phr}$ ), $\mathrm{ZnO}, 6 \mathrm{PPD}$ and stearic acid in the internal mixer at $90{ }^{\circ} \mathrm{C}$ with $60 \mathrm{rpm}$ rotor speed for $10 \mathrm{~min}$. For the compound containing only conventional filler the NR was mixed together with $58 \mathrm{phr} \mathrm{N} 330$, the $\mathrm{ZnO}$, 6PPD and stearic acid in the internal mixer at $90{ }^{\circ} \mathrm{C}$ with
$60 \mathrm{rpm}$ rotor speed for $10 \mathrm{~min}$. In the last step of the preparation the vulcanization accelerators TBBS and CBS together with the sulfur were added in an open two roll mill (Polymix 110 L, size: 203 $\mathrm{mm} \times 102 \mathrm{~mm}$ Servitec GmbH, Wustermark, Germany) at $90{ }^{\circ} \mathrm{C}$. The milling was performed at 0.5 $\mathrm{mm}$ and later at $0.3 \mathrm{~mm}$ nip gap for $5 \mathrm{~min}$. The formulations of NR compounds expressed as parts per hundred of rubber (phr) are shown in Table 1. The test samples were molded and cured to $2 \mathrm{~mm}$ tick plates by compression molding $(150 \mathrm{kN})$ on an electrically heated hydraulic press at $150{ }^{\circ} \mathrm{C}$. The rubber samples were vulcanized up to their respective optimum cure time $\left(t_{90}\right)$, previously determined with a vulcameter (Scarabaeus, Langgöns, Germany), and then stored for $24 \mathrm{~h}$ before the tests were performed.

Table 1. Formulation of the NR compounds

\begin{tabular}{lccccc}
\hline Sample code & NR $^{*}$ & MWCNT & EOMt & N330 & Ultrasil VN3 \\
\hline NR-gum & 100 & 0 & 0 & 0 & 0 \\
NR-h-CB40-S0 & 100 & 2 & 16 & 40 & 0 \\
NR-h-CB20-S20 & 100 & 2 & 16 & 20 & 20 \\
NR-h-CB0-S40 & 100 & 2 & 16 & 0 & 40 \\
NR-CB58 & 100 & 0 & 0 & 58 & 0 \\
\hline
\end{tabular}

*Mass of the ingredients was taken in parts per hundred of rubber (phr). The ingredients which amounts were kept constant in all compounds were ZnO $5 \mathrm{phr}$, stearic acid $2 \mathrm{phr}$, 6PPD $1 \mathrm{phr}$, CBS $1.5 \mathrm{phr}$, TBBS $0.2 \mathrm{phr}$ and sulfur $1.5 \mathrm{phr}$.

\section{Characterization}

Curing studies were performed using Scarabaeus SIS-V50, a rubber processing analyzer (Scarabaeus, Langgöns, Germany) in the isothermal time sweep mode at $150^{\circ} \mathrm{C}$ for $60 \mathrm{~min}$.

Amplitude sweep measurements of the dynamic mechanical analysis were performed on rectangular samples with dimensions $10 \mathrm{~mm} \times 35 \mathrm{~mm}$ using an Eplexor $2000 \mathrm{~N}$ (NETZSCH GABO Instruments $\mathrm{GmbH}$, Ahlden, Germany) in the tension mode at room temperature, at a frequency of $2 \mathrm{~Hz}$, a static tensile load of $60 \%$ pre-strain was applied and then the samples were oscillated to a dynamic load from $0 \%$ to $40 \%$ strain, and at a frequency of $10 \mathrm{~Hz}$, a static tensile load of $60 \%$ pre-strain was applied and then the samples were oscillated to a dynamic load from $0 \%$ to $50 \%$ strain.

\section{RESULTS AND DISCUSSION}

The rheometric curves and rheometric characteristics of the gum compound and the com- pounds with hybrid nano- and conventional fillers are shown in Figure 1 and Table 2, respectively. It is evident that the presence of fillers (both hybrid and conventional) results in an increase of the maximum rheometric torque as compared to the gum.

The compound containing $40 \mathrm{phr}$ of reinforcing $\mathrm{CB}$ and the hybrid nanofiller (2 phr MWCNT and 16 phr EOMt) showed the highest maximum torque value and then it decreases with the decrease of the CB and increase of silica content. The lowering of the torque in the filled rubber compounds is a common fact when non-reinforcing clay, calcium carbonate and silica without silane coupling agent, such as in this case, are used as fillers [25]. The influence of the different fillers on the curing parameters is quite complex. The scorch time reduces significantly when $40 \mathrm{phr} \mathrm{CB}$ and the hybrid nanofiller are added to the gum compound, from 6.54 minutes to 1.74 minutes. For both nanofillers such an effect is already reported [1, 26, 27]. At present there are no clear explanations how MWCNT interfere with the cure chemistry, but it is plausible to 
think that the catalyst employed for the synthesis of MWCNT which remained trapped inside the carbon material may affect the vulcanization [27]. On the other hand, the accelerating effect of the organoclay is essentially attributed to the presence of an amine modifier inserted into the clay galleries, since it is well known that amine groups activate the functional groups of the accelerants, giving rise to a synergic effect that leads to a faster and more effective vulcanization reaction $[1,27]$.

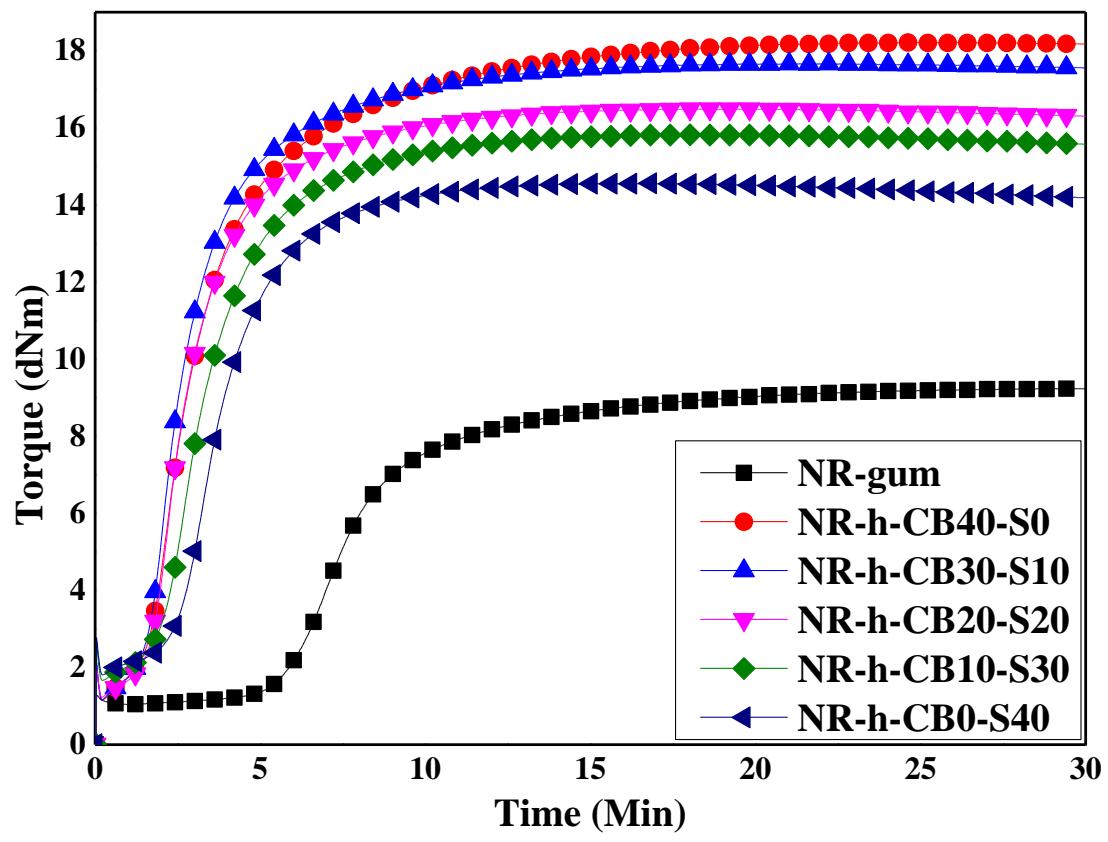

Figure 1. Rheometric curves if the gum compound and the compounds with hybrid nano- and conventional fillers

Table 2. Curing characteristics of the NR based compounds

\begin{tabular}{lccccc}
\hline Compound & $\begin{array}{c}\text { Minimum } \\
\text { rheometric } \\
\text { torque }\left(R_{\min }\right)\end{array}$ & $\begin{array}{c}\text { Maximum } \\
\text { rheometric } \\
\text { torque }\left(R_{\infty}\right)\end{array}$ & $\begin{array}{c}\text { Scorch } \\
\text { time } t_{2}\end{array}$ & $\begin{array}{c}\text { Cure rate } \\
\text { index }(\mathrm{CRI}) \\
100 /\left(t_{90}-t_{2}\right)\end{array}$ & $\begin{array}{c}\text { Curing } \\
\text { time }\left(t_{90}\right)\end{array}$ \\
\hline NR-gum & $\mathrm{dNm}$ & $\mathrm{dNm}$ & $\min$ & $\mathrm{min}^{-1}$ & $\min$ \\
NR-h-CB40-S0 & 1.04 & 9.24 & 6.54 & 14.88 & 13.26 \\
NR-h-CB30-S10 & 1.16 & 18.22 & 1.74 & 15.50 & 8.19 \\
NR-h-CB20-S20 & 1.15 & 17.66 & 1.66 & 21.32 & 6.35 \\
NR-h-CB10-S30 & 1.23 & 16.49 & 1.82 & 23.36 & 6.10 \\
NR-h-CB0-S40 & 1.66 & 15.82 & 2.18 & 22.17 & 6.69 \\
\hline
\end{tabular}

The same trend of changes can be observed in the optimum cure time (given by $t_{90}$ ). What is interesting is its significant reduction when silica filler is introduced into the compound. The introduction of silica also markedly influences the curing kinetics of the compounds, which can be interpreted in terms of the cure rate index (CRI). CRI is a parameter proportional to the average slope of the cure curve $\left(100 / t_{90}-t_{2}\right)$ in the curing step region. The higher the value of CRI, the faster is the curing process. It is apparent that the curing rate is significantly increased when silica is added to the com- pound compared to the gum and the compound containing the hybrid nanofillers and only $\mathrm{CB}$. This influence of silica on the curing parameters is in agreement with other studies which reported similar phenomena $[28,29]$. This higher viscosity could be also observed as higher values of minimum torque determined from rheometer cure curves (Figure 1). In order to explore the rubber-filler and filler-filler interactions in these complex NR-based composites DMA strain sweep measurements were performed at two different frequencies $2 \mathrm{~Hz}$ and $10 \mathrm{~Hz}$. 


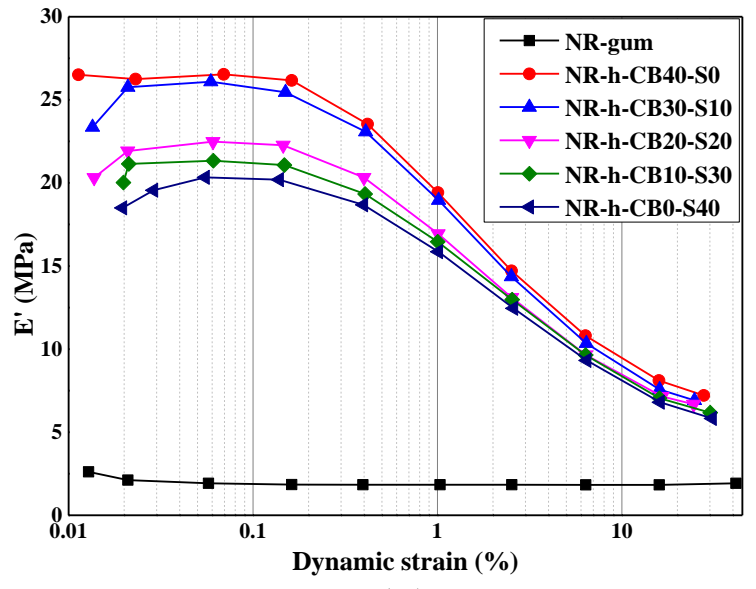

(a)

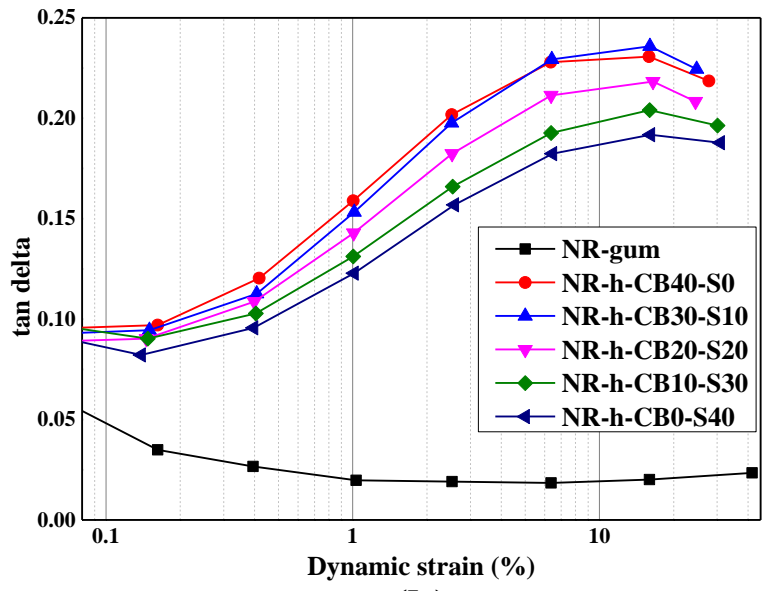

(b)

Figure 2. Strain dependence of $E^{\prime}$ (a) and $\tan \delta$ (b) for the NR-gum and NR composites at $2 \mathrm{~Hz}$

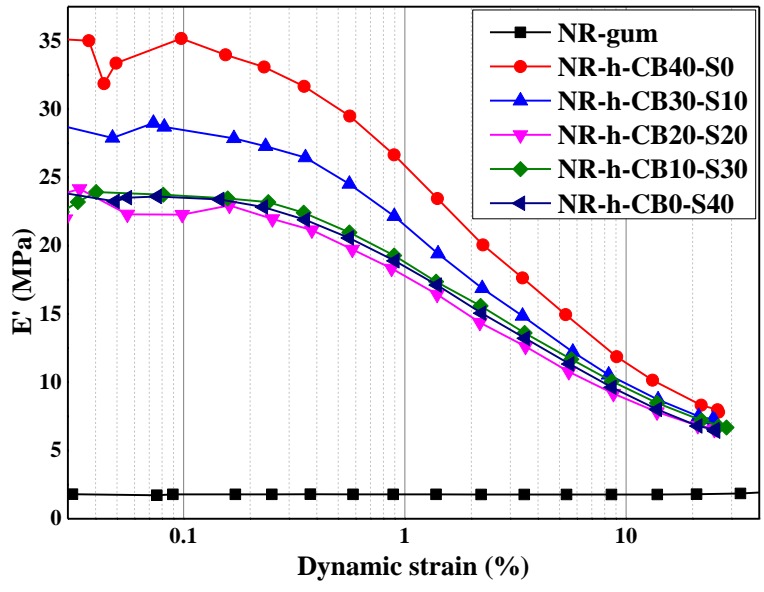

(a)

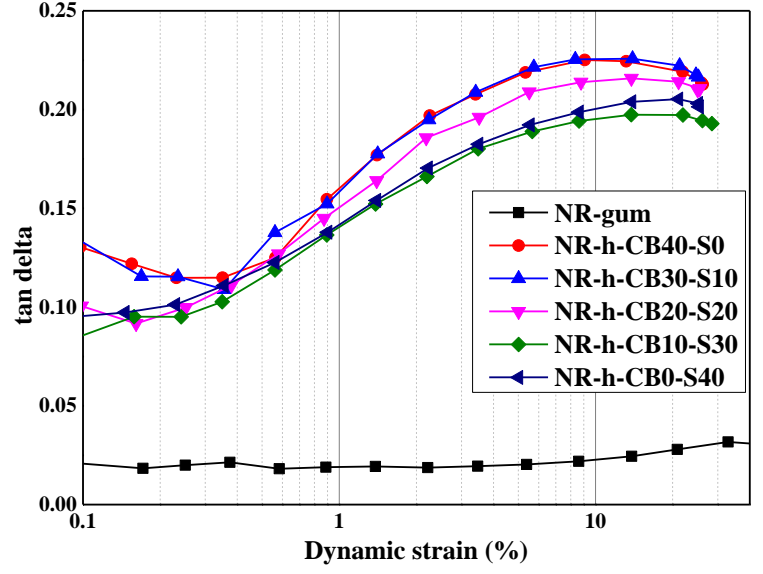

(b)

Figure 3. Strain dependence of $E^{\prime}$ (a) and $\tan \delta$ (b) for the NR-gum and NR composites at $10 \mathrm{~Hz}$

It is well known that the storage modulus for the filled rubbers depends on deformation amplitude, besides on frequency and temperature. This nonlinear behavior is the so called Payne effect [30, $31]$ and is explained with the existence of a fillerfiller network in the polymer matrix, above the filler percolation threshold. The strain dependence of the storage modulus $\left(E^{\prime}\right)$ and the loss factor $(\tan \delta)$ at $2 \mathrm{~Hz}$ and $10 \mathrm{~Hz}$ are reported in Figure $2 \mathrm{a}$ and b and in Figure $3 a$ and $b$, respectively, for the NRgum compound and the NR composites containing conventional and hybrid nanofillers. There is a pronounced non-linear strain dependence of the storage modulus (Figures 2a and 3a) for all composites, especially for those containing high $\mathrm{CB}$ content (NR-h-CB40-S0, NR-h-CB30-S10). It is interesting to note that there is a more pronounced difference between the storage modulus of the compounds containing a high amount of $\mathrm{CB}$ at higher frequen- cy of $10 \mathrm{~Hz}$, while for the compounds with a high silica content this difference is more pronounced at lower frequency of $2 \mathrm{~Hz}$. This is connected to the structure of the filler networks and the way they respond to a cyclic dynamic strain. Tan $\delta$ (a measure of the dissipation energy) follows this trend, namely, a remarkable increase for all composites, especially for those containing high amounts of $\mathrm{CB}$, compared to the NR-gum.

To understand deeply the Payne effect and to describe this strain-dependency of the storage modulus, we will use the cluster-cluster aggregation (CCA) model. The storage modulus, well above the percolation threshold, can be approximated by a function of the Havriliak-Negami type [32]:

$$
\Delta G^{\prime}\left(\gamma_{0}\right) \cong \Delta G_{0}^{\prime}\left[1+\left(\frac{\gamma_{0}}{\gamma_{c}}\right)^{2 m}\right]^{-\tau}
$$


Here, $\gamma_{c}$ is the strain amplitude, where half of the clusters are broken, $m$ being an empirical exponent and $\tau \approx 3.6$ is the elasticity exponent of percolation [33].

The theoretical models for filled rubber are developed for shear modes but we attempted to use this model to predict the dynamic behavior in tension mode.

Figure 4 and Figure 5 show the experimental results of the strain-dependency of the modulus $E$, for the different NR based composites containing different combinations of fillers and as seen already with this approximation a fairly good description of the Payne effect is possible. The solid lines correspond to fitted curves according to Eq. (1).
The fitting parameters $\Delta E^{\prime}{ }_{0}, \gamma_{c}, E_{\infty}^{\prime}$, and $m$ are summarized in Table 3. It becomes obvious that their values are affected by the type of the fillers present in the NR matrix but also by the frequency, except for the empirical Kraus-parameter $m$. The composites containing more $\mathrm{CB}$ exhibit a more pronounced Payne effect, which is reflected in the highest value of $\Delta E^{\prime}{ }_{0}$ for the NR-h-CB40-S0 composite. Addition of silica reduces the $\Delta E^{\prime}{ }_{0}$ value which is lowest for NR-h-CB0-S40 composite. The same trend is observed for both frequencies with the difference that for the higher frequency of 10 $\mathrm{Hz}$ the Payne effect is more pronounced than for the frequency of $2 \mathrm{~Hz}$.

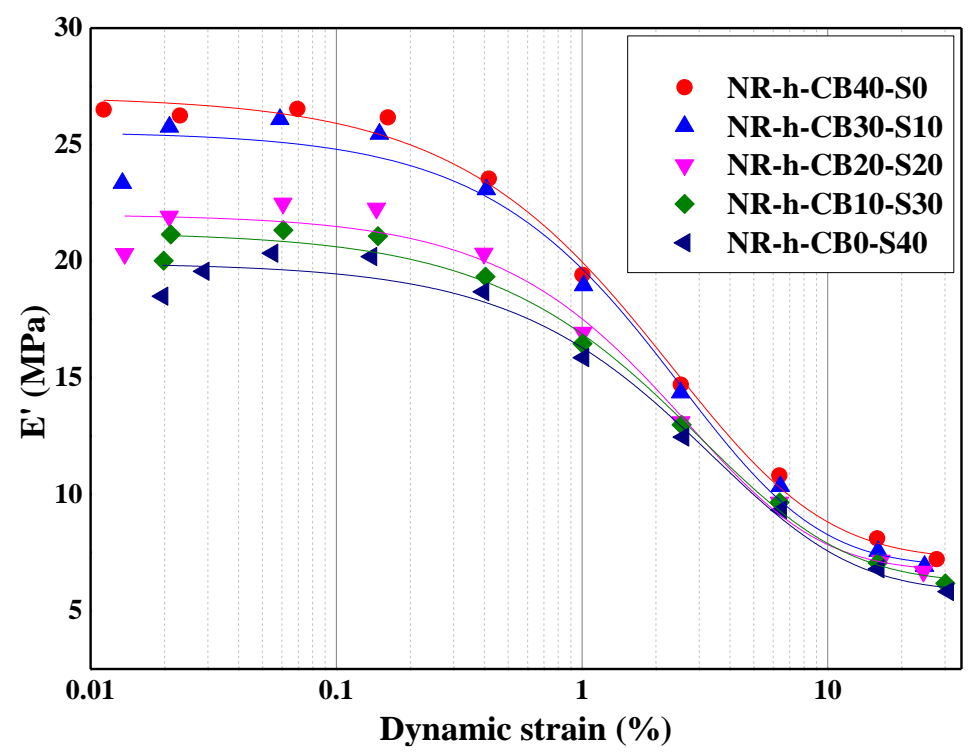

Figure 4. Plot of storage modulus vs. strain amplitude for the different NR based composites at $2 \mathrm{~Hz}$

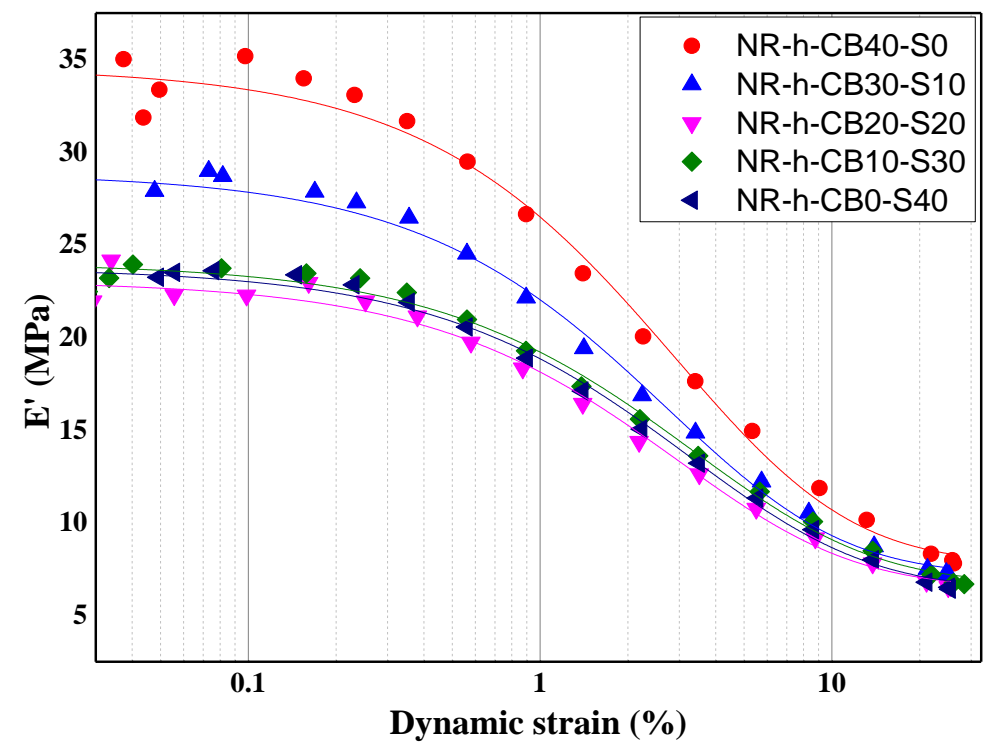

Figure 5. Plot of storage modulus vs. strain amplitude for the different NR based composites at $10 \mathrm{~Hz}$ 
Table 3. Material parameters from least square fits of Eq. (1) to the experimental data shown in Figure $4(\tau=3.6)$

\begin{tabular}{lcccc}
\hline Composite & $\Delta E^{\prime}{ }_{0}(\mathrm{MPa})$ & $\gamma_{c}(\%)$ & $m$ & $E_{\infty}^{\prime}(\mathrm{MPa})$ \\
\hline NR-h-CB40-S0 & 18.9 & 9.9 & 0.44 & 7.2 \\
NR-h-CB30-S10 & 18.7 & 9.3 & 0.49 & 6.9 \\
NR-h-CB20-S20 & 15.3 & 9.5 & 0.51 & 6.7 \\
NR-h-CB10-S30 & 15.0 & 12.12 & 0.46 & 6.2 \\
NR-h-CB0-S40 & 14.12 & 12.91 & 0.47 & 5.8 \\
\hline
\end{tabular}

Table 4. Material parameters from least square fits of Eq. (1) to the experimental data shown in Figure $5(\tau=3.6)$

\begin{tabular}{lcccc}
\hline Composite & $\Delta E^{\prime}{ }_{0}(\mathrm{MPa})$ & $\gamma_{c}(\%)$ & $m$ & $E_{\infty}^{\prime}(\mathrm{MPa})$ \\
\hline NR-h-CB40-S0 & 26.8 & 11.9 & 0.46 & 7.8 \\
NR-h-CB30-S10 & 21.6 & 11.1 & 0.46 & 7.2 \\
NR-h-CB20-S20 & 16.6 & 12.2 & 0.46 & 6.5 \\
NR-h-CB10-S30 & 16.6 & 12.2 & 0.46 & 6.7 \\
NR-h-CB0-S40 & 17.3 & 13.6 & 0.45 & 6.4 \\
\hline
\end{tabular}

A similar behavior is observed for the large strain $E_{\infty}^{\prime}$ values that are dominated by the pronounced hydrodynamic amplification of structured particles like CB. $E_{\infty}^{\prime}$ is the highest for the NR-hCB40-S0 composite and then its value decreases with increase of silica content. On the other hand, these structured filler particles like $\mathrm{CB}$, lead to a lower stability of the filler network, as seen by the lower $\gamma_{c}$-values for the composites containing more CB (NR-h-CB40-S0 and NR-h-CB30-S10). This value of $\gamma_{c}$ (the strain amplitude, where half of the clusters are broken) increases when silica is more present in the NR matrix. The largest $\gamma_{\mathrm{c}}-$ values of $12.91 \%$ and $13.6 \%$ (for $2 \mathrm{~Hz}$ and $10 \mathrm{~Hz}$ respectively) are found for the NR-h-CB0-S40 composite, suggesting the highest stability, which is due to poor compatibility of silica filler to hydrocarbon rubber, its polar character and the ability to form hydrogen bonds [34]. The empirical Kraus-parameter $m$, that considers the power law dependency of the number of surviving clusters on the applied strain, shows very small variation with the type of applied fillers and also negligible variations with frequency [32].

\section{CONCLUSION}

Based on the above work, devoted to thorough rheometric and dynamical mechanical analyses of complex NR based composites, the following conclusions can be drawn.
The rheometric studies showed the highest maximum torque value for the composite containing $40 \mathrm{phr} \mathrm{CB}$ and then it decreased with decrease of $\mathrm{CB}$ and increase of the silica content. The scorch time and optimum cure time reduced significantly when $40 \mathrm{phr} \mathrm{CB}$ and the hybrid nanofiller were added to the gum compound and further decreased with addition of silica, suggesting a better processability of these rubber composites and faster curing process.

The dynamic mechanical analysis showed a pronounced non-linear strain dependence of the storage modulus and a remarkable increase of the loss factor $\tan \delta$ for all composites, especially for those containing high $\mathrm{CB}$ content, compared to the NR-gum. The influence of the frequency on the storage modulus was as follows: a more pronounced difference between the storage modulus of the composites containing high CB content at higher frequency of $10 \mathrm{~Hz}$, and opposite to this, a more pronounced difference for the composites containing high silica content at lower frequency of $2 \mathrm{~Hz}$. This might be connected to the structure of the filler networks and the way they respond to a cyclic dynamic strain.

The CCA-model gave a fairly good description of the Payne effect. From the calculated parameters $\Delta E^{\prime}{ }_{0}, \gamma_{c}$ and $E_{\infty}^{\prime}$ it is obvious that their values are affected by the type of the fillers present in the NR matrix but also by the frequency. The composites containing more CB exhibit more pronounced Payne effect, a trend that is observed for 
both frequencies with that difference that for the higher frequency of $10 \mathrm{~Hz}$ the Payne effect is more pronounced. On the other hand, CB as structured filler particles, lead to a lower stability of the filler network, as seen by the lower $\gamma_{c}$-values for the composites containing more CB (NR-h-CB40-S0 and NR-h-CB30-S10). This value of $\gamma_{c}$ increases when silica is more present in the NR matrix, suggesting a higher stability, which is due to poor compatibility of silica filler to hydrocarbon rubber, its polar character and the ability to form hydrogen bonds.

\section{REFERENCES}

[1] A. Ivanoska-Dacikj, G. Bogoeva-Gaceva, A. Buzarovska, I. Gjorgjiev, Lj. Raka, Preparation and properties of natural rubber/organo-montmorillonite: from lab samples to bulk material, Maced. J. Chem. Chem. En., 33 (2) (2014), pp. 249-265.

[2] S. B. Eshwaran, D. Basu, S. R. Vaikuntam, B. Kutlu, S. Wiessner, A. Das, K. Naskar, G. Heinrich, Exploring the role of stearic acid in modified zinc aluminum layered double hydroxides and their acrylonitrile butadiene rubber nanocomposites, J. Appl. Polym. Sci., 132 (2015) 41539.

[3] M. Galimberti, S. Giudice, V. Cipolletti, G. Guerra, Control of organoclay structure in hydrocarbon polymers, Polym. Advan. Technol., 21 (2010), pp. 679-684.

[4] A. Das, K. W. Stöckelhuber, R. Jurk, D. Jehnichen, G. Heinrich, A general approach to rubber-montmorillonite nanocomposites: Intercalation of stearic acid, Appl. Clay. Sci., 51 (2011), pp. 117-125.

[5] S. Rooj, A. Das, K. W. Stöckelhuber, U. Reuter, G. Heinrich, Highly exfoliated natural rubber/clay composites by "propping-open procedure": the influence of fatty acid chain length on exfoliation, Macromol. Mater. Eng., 297 (4) (2012), pp. 369-383.

[6] S. Rooj, A. Das, K. W. Stöckelhuber, N. Mukhopadhyay, A. R. Bhattacharyya, D. Jehnichen et al., Pre-intercalation of long chain fatty acid in the interlayer space of layered silicates and preparation of montmorillonite/natural rubber nanocomposites, Appl. Clay. Sci., 67 (2012) pp. 50-56.

[7] A. Usuki, A. Tukigase, M. Kato, Preparation and properties of EPDM-clay hybrids, Polymer, 43 (8) (2002), pp. 2185-2189.

[8] R. Magaraphan, W. Thaijaroen, R. Lim-Ochakun, Structure and properties of natural rubber and modified montmorilonite nanocomposites, Rubber. Chem. Technol., 76 (2) (2003), pp. 406-418.

[9] M. A. López-Manchado, B. Herrero, M. Arroyo, Organoclay-natural rubber nanocomposites syn- thesized by mechanical and solution mixing methods, Polym. Int., 53 (2004), pp. 1766-1772.

[10] S. Varghese, J. Karger-Kocsis, Natural rubberbased nanocomposites by latex compounding with layered silicates, Polymer, 44 (2003), pp. 49214927.

[11] M. Hoikkanen, M. Poikelispää, A. Das, M. Honkanen, W. Dierkes, J. Vuorinen, Effect of multiwalled carbon nanotubes on the properties of EPDM/NBR dissimilar elastomer blends, Polym.Plast. Technol., 54 (2015), pp. 402-410.

[12] H. H. Le, S. Abhijeet, S. Ilisch, J. Klehm, S. Henning, M. Beiner, S. S. Sarkawi, W. Dierkes, A. Das, D. Fischer, K. W. Stöckelhuber, S. Wießner, S. P. Khatiwada,R. Adhikari, T. Pham, G. Heinrich, H. J. Radusch, The role of linked phospholipids in the rubber-filler interaction in carbon nanotube (CNT) filled natural rubber (NR) composites, Polymer, 55 (2014), pp. 4738-4747.

[13] H. H. Le, M. Parsekar, S. Ilisch, S. Henning, A. Das, K. W. Stöckelhuber, M. Beiner, C. A. Ho, R. Adhikari, S. Wießner, G. Heinrich, H. J. Radusch, Effect of non-rubber components of NR on the carbon nanotube (CNT) localization in SBR/NR blends, Macromol. Mater .Eng., 299 (2014), pp. 569-582.

[14] N. Mahmood, A. U. Khan, M. S. Khan, K. W. Stöckelhuber, A. Das, D. Jehnichen, G. Heinrich, Carbon nanotubes filled thermoplastic polyurethane-urea and carboxylated acrylonitrile butadiene rubber blend nanocomposites, J. Appl. Polym. Sci., 131 (2014) 40341.

[15] H. H. Le, M. Sriharish, S. Henning, J. Klehm, M. Menzel, W. Frank, S. Wießner, A. Das, K. W. Stöckelhuber, G. Heinrich, H. J. Radusch, Dispersion and distribution of carbon nanotubes in ternary rubber blends, Compos. Sci. Technol., 90 (2014), pp. 180-186.

[16] A. Das, K. W. Stöckelhuber, R. Jurk, M. Saphiannikova, J. Fritzsche, H. Lorenz et al., Modified and unmodified multiwalled carbon nanotubes in high performance solution-styrene-butadiene and butadiene rubber blends, Polymer, 49 (24) (2008), pp. 5276-5283.

[17] H. Dai, Carbon nanotubes: opportunities and challenges, Surf. Sci., 500 (2002), pp. 218-241.

[18] M. Galimberti, V. Kumar, M. Coombs, Cipolletti V. et. al., Filler networking of a nanographite with a high shape anisotropy and synergism with carbon black in poly(1,4-cisisoprene)-based nanocomposites, Rubber Chem. Technol., 87 (2014), pp. 197-218.

[19] P. K. Chattopadhyay, N. C. Das and S. Chattopadhyay, Influence of interfacial roughness and the hybridfiller microstructures on the properties of ternary elastomeric composites, Compos. Part AAppl. S., 42 (2011), pp. 1049-1059. 
[20] A. Malas, C. K. Das, Carbon black-clay hybrid nanocomposites based upon EPDM elastomer, $J$. Mater. Sci., 47 (2012), pp. 2016-2024.

[21] M. Galimberti, M. Coombs, V. Cipolletti et. al., Enhancement of mechanical reinforcement due to hybridfiller networking promoted by an organoclay in hydrocarbon-based nanocomposites, Appl. Clay. Sci., 65-66 (2012), pp. 57-66.

[22] A. Ivanoska-Dacikj, G. Bogoeva-Gaceva, S. Rooj, G. Heinrich, S. Wießner. Fine tuning of the dynamic mechanical properties of natural rubber/carbon nanotube nanocomposites by organically modified montmorillonite: A first step in obtaining high-performance damping material suitable for seismic application, Appl. Clay. Sci., 118 (2015), pp. 99-106.

[23] M. J. Wang, The role of filler networking in dynamic properties of filled rubber, Rubber Chem. Technol., 72 (1999), pp. 430-448.

[24] Z. E. Erisen and E. Cigeroglu, Frequency domain optimization of dry friction dampers on buildings under harmonic excitation, in: J. Caicedo, F. N. Catbas, A. Cunha, V. Racic, P. Reynolds, K. Salyards (Eds.), Topics on the Dynamics of Civil Structures, Volume 1, Proceedings of the 30th IMAC, A Conference and Exposition on Structural Dynamics, Springer; 2012, pp. 113-126.

[25] A. K. Ghosh, A. Das, D. K. Basu, Effect of Bis(diisopropyl)thiophosphoryl disulfide on the covulcanization of styrene-butadiene rubber and ethylene-propylene-diene (monomer) blends, $J$. Appl. Polym. Sci., 92 (2004), pp. 123-142.

[26] F. Cataldo, O. Ursini, G. Angelini, MWCNTs Elastomer nanocomposite, Part 1: The addition of MWCNTs to a natural rubber-based carbon black- filled rubber compound, Fuller. Nanotub. Car. N., 17 (2009), pp. 38-54.

[27] R. Verdejo, M. Hernandez, N. Bitnis, J. M. Kenny, M. A. Lopez-Manchando, Vulcanization characteristics and curing kinetics of rubber-organoclay nanocomposites, in: M. Galimberti (Ed.), Rubber Clay Nanocomposites - Science, Technology and Applications, New York: Wiley and Sons; 2011, pp. 275-303.

[28] S. S. Choi, C. Nah, B. W. Jo, Properties of natural rubber composites reinforced with silica or carbon black: influence of cure accelerator content and filler dispersion, Polym. Int., 52 (2003), pp. 1382-1389.

[29] N. Rattanasom, T. Saowapark, C. Deeprasertkul, Reinforcement of natural rubber with silica/carbon black hybrid filler, Polym. Test., 26 (2007), pp. 369-377.

[30] A. R. Payne, The dynamic properties of carbon black-loaded natural rubber vulcanizates, Part I, $J$. Appl. Polym. Sci., 6 (1962), pp. 57-63.

[31] A. R. Payne and R. E. Whittaker, Influence of hysteresis on tensile and fatigue failure in rubbers, $J$. Appl. Polym. Sci., 15 (1971), pp. 1941-1948.

[32] G. Heinrich, M. Klüppel, Recent advances in the theory of filler networking in elastomers, in: K.S. Lee (Ed.), Filled elastomers drug delivery systems series: Advances in polymer science, Vol 160, Springer, Berlin, 2002, pp. 1-44.

[33] Y. Kantor and I. Webman, Elastic properties of random percolating systems, Phys. Rev. Lett., 52 (1984), pp. 1891-1894.

[34] J. H. Bachmann, J. W. Sellers, M. P. Wagner, R. F. Wolf, Fine particle reinforcing silicas and silicates in elastomers, Rubber Chem. Technol., 32 (1959), pp. 1286-1391.

\title{
РЕОМЕТРИСКА И ДИНАМИЧКО-МЕХАНИЧКА АНАЛИЗА НА КОМПЛЕКСНИ КОМПОЗИТИ БАЗИРАНИ НА ПРИРОДНА ГУМА
}

\author{
Александра Иваноска-Дациќ ${ }^{1 *}$, Гордана Богоева-Гацева ${ }^{1,2}$, Свен Виснер ${ }^{3,4}$, Герт Хајнирх ${ }^{3,4}$ \\ ${ }^{1}$ Истражувачки центар за животна средина и материјали, \\ Македонска академија на науките и уметностите, Скопје, Република Македонија \\ ${ }^{2}$ Технолошко-металуршки факултет, Универзитет „Св. Кирил и Методиј“, \\ Скопје, Република Македонија \\ 3 Лајбниц институт за полимерни истражувања - Дрезден, Германија \\ ${ }^{4}$ Институт за материјали, Технички универзитет во Дрезден, Германија
}

Во овој труд се опфатени подготовката и карактеризацијата на комплексни композити на база на природна гума, кои содржат хибридни нано- и конвенционални полнила, а кои се наменети за сеизмичка базна изолација. Извршена е темелна реометриска и динамичко-механичка анализа (режим на смолкнување при фреквенции од $2 \mathrm{~Hz}$ и $10 \mathrm{~Hz}$ ) на овие комплексни композити кои содржат хибридно нанополнило, составено од јаглеродни наноцевчиња и експандиран монтморилонит и различни количини конвенционални полнила, саѓ и силициум диоксид. Реометриската анализа покажа дека влијанието на комбинациите од различни полнила врз параметрите на вмрежување е комплексно, но присуството на полнила главно го 
намалува т.н. „скорч” време и времето на оптимално вмрежување. Динамичката механичка анализа покажа изразена нелинеарна зависност на модулите на еластичност од напрегање и значително зголемување на факторот на загуба, $\tan \delta$, за сите композити, особено за оние кои содржат голема количина саѓи. За да се опише зависноста на модулите на еластичност од напрегањето, искористен е моделот на кластер-кластерска агрегација. Се покажа дека вредностите на фитуваните параметри $\Delta E^{\prime}{ }_{0}, \gamma_{c}$, и $E_{\infty}{ }_{\infty}$ пресметани според овој модел зависат од типот на полнилото присутно во еластомерната матрица, но и од применетата фреквенција.

Клучни зборови: природна гума; реометриска анализа; вмрежување на полнило; ефект на Пајн 